\title{
Pengaruh Penggunaan Media Audiovisual dan Minat Belajar Siswa terhadap Pembelajaran Menulis Puisi pada Siswa Kelas X SMK Negeri di Kabupaten Karawang
}

\author{
Dwi Marta Gumilar1) \\ Universitas Indraprasta PGRI \\ Jalan Nangka No. 58 C/TB. Simatupang, Tanjung Barat, Jakarta Selatan 12530 \\ E. Zaenal Arifin') \\ Universitas Indraprasta PGRI \\ Jalan Nangka No. 58 C/TB. Simatupang, Tanjung Barat, Jakarta Selatan 12530 \\ Mamik Suendarti ${ }^{3)}$ \\ Universitas Indraprasta PGRI \\ Jalan Nangka No. 58 C/TB. Simatupang, Tanjung Barat, Jakarta Selatan 12530 \\ gumilardwimarta@gmail.com ${ }^{1)}$, zaenalarifin_48@yahoo.com ${ }^{2)}$, \\ mamik.suendarti@unindra.ac.id ${ }^{3)}$
}

\begin{abstract}
This study aims to determine (1) the effect of using audio visual media and learning interest jointly towards students' ability in writing poetry (2) The effect of using audio visual media towards students' ability in writing poetry (3) The influence of students' learning interest towards students' ability in writing poetry. The research was conducted using a survey method. The population in this study were students from $10^{\text {th }}$ grade of Vocational High School in Karawang Regency with a sample size of 88 students. The sampling technique used was multistage random sampling. The instruments used in the study were a questionnaire in the form of a Google Form and a writing skill test. Data analysis using multiple linear regression. The results of hypothesis testing obtained the following conclusions: (1) There is a significant effect on the use of instructional media and interest in learning jointly towards students' ability in writing poetry. It can be proved that the Sig. $0.000<0.05$ and the calculated $F$ value of 715.855> 3.95. (2) There is a significant effect of using audio visual media towards students' ability in writing poetry. It can be proved that the value of Sig $=0.000<0.05$ and tobserved $=25.357>1.987$. (3) There is a significant effect of students' learning interest towards students' ability in writing poetry. It can be proved that Sig $=0.000<0.05$ and tobserved $=22,672>$ 1,987. The implication in this research is that the use of audio-visual media, especially documentary films, and support for learning interest are sufficient to influence the ability to write descriptive texts for the better.
\end{abstract}

Keywords: Learning Media, Audio Visual Media, Learnig Interest, Indonesian Poetry Writing Lessons.

\begin{abstract}
Abstrak
Penelitian ini bertujuan untuk mengetahui (1) Pengaruh penggunaan media audio visual dan minat belajar secara bersama-sama terhadap kemampuan menulis puisi pada siswa kelas X SMK Negeri di kabupaten Karawang (2) Pengaruh penggunaan media audio visual terhadap kemampuan menulis puisi pada siswa kelas X SMK Negeri di kabupaten Karawang (3) Pengaruh minat belajar siswa terhadap kemampuan menulis puisi pada siswa kelas X SMK Negeri di kabupaten Karawang. Penelitian dilakukan dengan metode survei. Populasi pada penelitian ini yaitu siswa kelas X SMK Negeri di Kabupaten Karawang dengan besar sampel sebanyak 88 siswa dengan teknik sampling yang digunakan yaitu multistage random sampling. Instrumen yang digunakan dalam penelitian
\end{abstract}


yaitu berupa kuesioner dalam bentuk Google Form dan tes kemampuan menulis. Analisis data menggunakan regresi linear berganda. Hasil pengujian hipotesis diperoleh kesimpulan sebagai berikut: (1) Terdapat pengaruh signifikan secara bersama-sama atas penggunaan media pembelajaran dan minat belajar terhadap kemampuan menulis puisi bahasa indonesia siswa kelas $\mathrm{X}$ SMK Negeri di Kabupaten Karawang. Hal ini dibuktikan dengan perolehan nilai Sig 0,000 < 0,05 serta nilai F hitung sebesar 715,855 > 3,95. (2) Terdapat pengaruh yang signifikan atas penggunaan media audio visual terhadap kemampuan menulis puisi pada siswa kelas X SMK Negeri di Kabupaten Karawang. Hal ini dibuktikan dengan perolehan nilai Sig $=0,000<0,05$ dan $t_{\text {hitung }}=$ $25.357>1.987$. (3) Terdapat pengaruh yang signifikan atas pengaruh minat belajar terhadap kemampuan menulis puisi bahasa indonesia siswa kelas X SMK Negeri di Kabupaten Karawang. Hal ini dibuktikan dengan perolehan nilai $\mathrm{Sig}=0,000<0,05$ dan $\mathrm{t}_{\text {hitung }}=22.672>1.987$. Implikasi dalam penelitian ini adalah Penggunaan media audio visual khususnya film dokumenter serta dukungan minat belajar cukup mampu mempengaruhi kemampuan menulis teks deskripsi menjadi lebih baik.

Kata Kunci: Media Pembelajaran, Media Audio Visual, Minat Belajar, Pembelajaran Menulis Puisi Bahasa Indonesia

\section{PENDAHULUAN}

Bahasa Indonesia merupakan salah satu mata pelajaran penting yang diajarkan dalam semua tingkat tataran pendidikan. Setiap keterampilan itu erat sekali berhubungan dengan tiga keterampilan lainnya dengan cara yang beraneka ragam. Dalam memperoleh keterampilan berbahasa, kita biasanya melalu suatu hubungan urutan yang teratur misalnya pada masa kecil kita belajar menyimak bahasa kemudian berbicara, sesudah itu kita belajar membaca dan menulis. Empat keterampilan itu tersebut pada dasarnya merupakan suatu kesatuan yaitu caturtunggal (Tarigan, 2013: 1). Keterampilan menulis tentu dikuasai oleh anak sejak anak mulai mengenal huruf atau angka tepatnya setelah anak bisa membaca. Karena menulis merupakan keterampilan produktif dalam proses pembelajaran bahasa Indonesia. Melalui menulis, siswa bisa menggali bakat dan potensi mereka, memacu peningkatan daya nalar, melatih konsentrasi, dan mengembangkan daya berpikir dalam melihat suatu masalah atau situasi yang ada disekitar mereka. Oleh karena itu, menulis memiliki peranan yang sangat penting khususnya dalam dunia pendidikan.

Menulis memiliki fungsi utama sebagai sarana untuk belajar. Siswa dapat mengungkapkan dan memunculkan ide serta pikirannya dalam bentuk tulisan sehingga secara tidak langsung akan melatih kemampuan berpikir siswa. Sehubungan dengan hal tersebut, Morsey (dalam Tarigan, 2013:4) juga mengatakan bahwa menulis dipergunakan orang terpelajar untuk mencatat atau merekam, melaporkan atau memberitahukan, meyakinkan, serta mempengaruhi. Mengingat pentingnya keterampilan menulis, maka kegiatan menulis sudah menjadi salah satu keterampilan yang wajib dikuasai siswa di sekolah.

Keterampilan menulis merupakan salah satu jenis keterampilan berbahasa yang harus dimiliki oleh siswa. Keterampilan menulis biasanya diartikan sebagai kemampuan mengungkapkan gagasan, pendapat dan perasaan kepada pihak lain melalui bahasa tulis. Keterampilan menulis juga merupakan suatu kegiatan yang produktif dan ekspresif (Tarigan, 2008:3). Sejalan dengan sastra, hal itu sangat menarik kaitannya dengan kemampuan (penguasaan kosakata dan imajinasi)

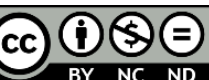

Creative Commons Attribution-NonCommercial-NoDerivatives 4.0 International License 
seseorang. Jika seseorang mampu berekspresi dengan baik, dan mampu menuangkannya dalam bentuk tulisan, itu berarti dia telah melakukan sebuah produksi berupa tulisan, dan tulisan yang dihasilkan bisa memberikan kepuasan terhadap diri sendiri bahkan orang lain. Oleh sebab itu, menulis (membuat karya sastra) adalah salah satu keterampilan yang perlu dikembangkan.

Keterampilan menulis kreatif sastra dalam pembelajaran Bahasa Indonesia dibagi ke dalam tiga kategori yaitu, puisi, prosa (fiksi), dan apresiasi drama (Suryaman, 2010:6). Bagi seorang siswa, tiga hal tersebut adalah keterampilan yang membutuhkan lebih banyak stimulus dibanding dengan keterampilan berbahasa yang lain. Hal tersebut dikarenakan oleh kurangnya minat siswa dalam pembelajaran karena dianggap sulit (Suryaman, 2010:66).

Namun dalam praktiknya pembelajaran menulis khususnya menulis puisi belum sepenuhnya sesuai dengan harapan. Masih ada beberapa peserta didik yang kesulitan dalam menuangkan ide, pikiran dan gagasannya kedalam bentuk puisi. Terdapat beberapa kendala yang dihadapi guru dan peserta didik dalam proses pembelajaran. Kendala yang dihadapi antara lain kurangnya pengetahuan peserta didik terhadap kemampuan menulis puisi, keterbatasan buku penunjang pembelajaran menulis khususnya menulis puisi, kurangnya pengembangan metode, teknik, dan media pembelajaran.

Permasalahan lain yang terlihat adalah masih kurangnya kemampuan menulis puisi pada peserta didik, aspek lain yang dapat mempengaruhi kemampuan menulis puisi siswa yaitu minat belajar. Minat belajar merupakan salah satu faktor yang sangat berpengaruh terhadap hasil belajar, dengan adanya minat dalam diri siswa terhadap bidang studi tertentu maka siswa tersebut akan cenderung untuk belajar dengan giat dan rajin sehingga pada akhirnya mencapai prestasi yang memuaskan. Senada dengan pendapat di atas, Dalyono (2009: 57) mengatakan bahwa minat belajar yang besar cenderung menghasilkan prestasi yang tinggi, sebaliknya minat belajar kurang akan menghasilkan prestasi yang rendah. hal ini dapat dilihat dari hasil belajar yang belum sepenuhnya memenuhi Kriteria Kelulusan Minimum (KKM). Kurangnya partisipasi peserta didik dalam mengikuti pembelajaran menulis khususnya menulis puisi juga menjadi kendala. Guru masih menggunakan pendekatan konvensional dalam pembelajaran menulis puisi. Hal tersebut mengakibatkan peserta didik pasif saat mengikuti Kegiatan Belajar Mengajar (KBM) di kelas. Peserta didik menganggap bahwa pelajaran menulis adalah suatu pelajaran yang sulit serta membosankan. Oleh karena itu, dapat disimpulkan bahwa minat belajar siswa akan meningkat jika penggunaan metode, model dan media pembelajaran yang tepat dalam proses pembelajaran.

Peneliti ingin menekankan pada sisi media pembelajaran yang memiliki fungsi utama untuk meningkatkan motivasi siswa dan mencegah kebosanan siswa dalam belajar. Media juga dapat menjadi alat bantu yang efektif ketika guru mampu mengemas media menjadi beberapa kegiatan untuk pengembangan diri siswa. Sebaliknya, media dapat menjadi beban baik dalam proses pemilihan maupun penggunaannya seandainya dengan media itu seluruh prosesnya dibebankan pada guru. Artinya, media akan menyebabkan sejenis katalisator untuk berbagi bertanggung jawab dalam pembelajaran. 
Untuk dapat meningkatkan kemampuan menulis khususnya menulis puisi pada siswa, perlu digunakan media pembelajaran yang menarik agar mampu menggugah minat peserta didik. Dengan demikian maka media yang dapat digunakan adalah media audio visual, media audio visual merupakan media berbasis suara dan gambar yang dapat digunakan dalam pembelajaran ini serta meningkatkan kemampuan menulis puisi.

Penggunaan media audio visual dapat meningkatkan minat ataupun ketertarikan siswa dan dapat merangsang siswa untuk lebih berpikir kritis dalam memahami lingkup sosial yang ada di sekitarnya. Media audio-visual menurut Munadi (2010:131) adalah media yang melibatkan indera pendengaran dan pengelihatan sekaligus dalam satu proses. Media audio-visual merupakan kombinasi dari media audio dan media visual atau biasa disebut media pandangdengar. Dengan menggunakan media audiovisual ini maka penyajian isi tema kepada anak akan semakin lengkap dan optimal. Selain itu media ini dalam batasbatas tertentu dapat menggantikan peran dan tugas guru. Dalam hal ini guru tidak selalu berperan sebagai penyampai materi karena penyajian materi bisa diganti oleh media. Peran guru bisa beralih menjadi fasilitator belajar, yaitu memberikan kemudahan bagi anak untuk belajar. Penggunaan media besar nilainya bagi pendidikan di sekolah, sehingga perlu digunakan dengan melalui prosedur kerja yang benar. Penggunaan media merupakan salah satu inovasi untuk meningkatkan mutu pendidikan, terutama di Indonesia. Bila pemanfaatannya tepat dalam kegiatan pembelajaran, penggunaan media akan berdampak langsung ataupun tidak langsung terhadap keaktifan siswa.

Penggunakan media audio visual diharapkan siswa lebih mudah dalam mengembangkan ide, pikiran, maupun gagasan yang akan dituangkan ke dalam tulisan puisi. Selain itu, proses belajar mengajar akan terasa lebih hidup dan lebih menyenangkan dibandingkan hanya dilaksanakan di dalam kelas. Oleh karena itu, penelitian ini bertujuan untuk mengetahui pengaruh penggunaan media audio visual dan minat belajar siswa terhadap pembelajaran menulis puisi.

\section{METODE}

Penelitian ini menggunakan pendekatan kuantitatif dengan desain penelitian berupa survei. Terdapat dua variabel bebas yaitu media pembelajaran Audio Visual $\left(\mathrm{X}_{1}\right)$ dan Minat Belajar $\left(\mathrm{X}_{2}\right)$, serta satu variabel terikat yaitu pembelajaran menulis puisi (Y).

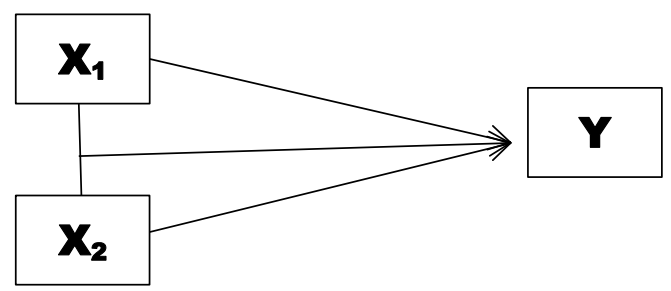

Gambar 1 Diagram Desain Regresi Linear Berganda 
Populasi pada penelitian ini yaitu kelas X SMK Negeri di Kabupaten Karawang dengan jumlah sample sebanyak 88 sampel dari total jumlah populasi sebanyak 752 populasi di 2 sekolah yakni SMK Negeri 1 Klari dan SMK Negeri 3 Karawang dengan teknik sampling yang digunakan yaitu multistage random sampling. Penelitian ini berlangsung selama satu bulan yakni pada bulan Desember 2020. Instrumen yang digunakan dalam penelitian yaitu berupa kuesioner dalam bentuk Google Form dan tes kemampuan menulis. Analisis data menggunakan regresi linear berganda yang diolah menggunakan program aplikasi IBM SPSS Statistics 25.0

\section{HASIL DAN PEMBAHASAN}

\section{Koefisien Relasi}

Koefisien ini menunjukan seberapa besar hubungan yang terjadi antara variabel Penggunaan Media pembelajaran $\left(\mathrm{X}_{1}\right)$ dan variabel Minat Belajar $\left(\mathrm{X}_{2}\right)$ secara bersama-sama terhadap variabel Kemampuan menulis puisi (Y).

Tabel 1 Hasil Nilai Koefisien Relasi

Model Summary

\begin{tabular}{|c|c|c|c|c|}
\hline Model & $\mathrm{R}$ & R Square & $\begin{array}{c}\text { Adjusted R } \\
\text { Square }\end{array}$ & $\begin{array}{l}\text { Std. Error of } \\
\text { the Estimate }\end{array}$ \\
\hline 1 & $.972^{\mathrm{a}}$ & .944 & .943 & 1.910 \\
\hline
\end{tabular}

a. Predictors: (Constant), Minat Belajar, Media

Pembelajaran

Berdasarkan tabel 1 diperoleh nilai $\mathrm{R}$ sebesar 0,972. Hal ini menunjukan bahwa hubungan antara variabel Penggunaan Media pembelajaran $\left(\mathrm{X}_{1}\right)$ dan variabel Minat Belajar $\left(\mathrm{X}_{2}\right)$ secara bersama-sama terhadap variabel Kemampuan menulis puisi (Y) adalah Sangat Kuat. Selain itu, terdapat nilai $\mathrm{R}^{2}$ (Adjusted $R$ Square) sebesar 0,944 atau $94.4 \%$. Hal ini menunjukan bahwa variasi variabel Penggunaan Media pembelajaran $\left(\mathrm{X}_{1}\right)$ dan variabel Minat Belajar $\left(\mathrm{X}_{2}\right)$ mampu menjelaskan sebesar $94.4 \%$ variabel Menulis puisi (Y).

Pengaruh Persepsi Atas Media Pembelajaran dan Minat Belajar Secara Bersama-Sama Terhadap Kemampuan Menulis Puisi

Untuk dapat menguji hipotesis pertama, maka data diolah menggunakan program IBM SPSS Statistics 25.0, dengan hasil data sebagai berikut : 
Tabel 2 Hasil Uji Hipotesis Pertama

\begin{tabular}{llrrrrr}
\multicolumn{7}{c}{ ANOVA $^{\mathbf{a}}$} \\
\hline \multirow{2}{*}{ Model } & \multicolumn{1}{c}{ Sum of } & Df & $\begin{array}{c}\text { Mean } \\
\text { Square }\end{array}$ & F & Sig. \\
& & Squares & & & & \\
\hline 1 & Regression & 5225.363 & 2 & 2612.682 & 715.855 & $.000^{\mathrm{b}}$ \\
& Residual & 310.228 & 85 & 3.650 & & \\
& Total & 5535.591 & 87 & & & \\
\hline
\end{tabular}

a. Dependent Variable: Menulis Puisi

b. Predictors: (Constant), Minat Belajar, Media Audio Visual

Berdasarkan hasil perhitungan ditabel 2 menunjukkan nilai Sig $0,000<0,05$ serta nilai $\mathrm{F}$ hitung sebesar $715,855>3,95$. Hal ini menunjukan bahwa terdapat pengaruh signifikan secara bersama-sama atas penggunaan media pembelajaran dan minat belajar terhadap kemampuan menulis puisi bahasa indonesia siswa kelas X SMK Negeri di Kabupaten Karawang. Dengan demikian, hipotesis pertama yang menyatakan "Terdapat pengaruh yang signifikan atas penggunaan media pembelajaran dan minat belajar secara bersama-sama terhadap pembelajaran menulis puisi siswa", terdukung/diterima.

Hal tersebut sejalan dengan penelitian yang dilakukan oleh Emeralda dkk. (2019) dalam jurnalnya "Peningkatan Motivasi dan Kemampuan Menulis Puisi dengan Media Audio Visual pada Siswa SMK" menyimpulkan bahwa peningkatan motivasi dan media audio visual mempengaruhi kemampuan menulis puisi menjadi lebik baik. Pada penelitian ini, penggunaan media audio visual dan minat belajar memiliki pengaruh yang sedang/cukup terhadap kemampuan menulis puisi siswa. Maka dapat dikatakan bahwa penggunaan media audio visual khususnya film dokumenter serta dukungan minat belajar cukup mampu mempengaruhi kemampuan menulis puisi menjadi lebih baik.

\section{Pengaruh Persepsi Atas Media Pembelajaran terhadap Kemampuan Menulis Puisi}

Untuk dapat menguji hipotesis kedua, maka data diolah menggunakan program IBM SPSS Statistics 25.0, dengan hasil data sebagai berikut :

Tabel 3 Hasil Uji Hipotesis Kedua

Coefficients $^{\text {a }}$

\begin{tabular}{|c|c|c|c|c|c|c|}
\hline \multirow{2}{*}{\multicolumn{2}{|c|}{ Model }} & \multicolumn{2}{|c|}{$\begin{array}{c}\text { Unstandardized } \\
\text { Coefficients }\end{array}$} & \multirow{2}{*}{$\begin{array}{c}\text { Standardized } \\
\text { Coefficients } \\
\text { Beta }\end{array}$} & \multirow[t]{2}{*}{$\mathrm{T}$} & \multirow[t]{2}{*}{ Sig. } \\
\hline & & B & $\begin{array}{l}\text { Std. } \\
\text { Error }\end{array}$ & & & \\
\hline \multirow[t]{2}{*}{1} & (Constant) & 7.575 & 1.928 & & 3.929 & .000 \\
\hline & $\begin{array}{l}\text { Media Audio } \\
\text { Visual }\end{array}$ & .467 & .018 & .664 & 25.357 & .000 \\
\hline
\end{tabular}

a. Dependent Variable: Menulis Puisi 
Berdasarkan hasil perhitungan pada tabel 3 media audio visual menunjukan nilai Sig $=0,000<0,05$ dan $t_{\text {hitung }}=25.357>1.987$. Hal ini menunjukan bahwa terdapat pengaruh yang signifikan atas penggunaan media audio visual terhadap kemampuan menulis puisi pada siswa kelas X SMK Negeri di Kabupaten Karawang. Dengan demikian, hipotesis kedua yang menyatakan terdapat pengaruh penggunaan media audio "terdapat pengaruh penggunaan media audio visual terhadap kemampuan menulis puisi pada siswa kelas X SMK Negeri di kabupaten Karawang", terdukung/diterima.

Hal tersebut sejalan dengan penelitian yang dilakukan oleh Supriantini (2017) dalam jurnalnya yang berjudul "Penerapan Media Audio Visual Dalam Meningkatkan Keterampilan Menulis Puisi Siswa Kelas VIII SMP Negeri 13 Palembang" menyimpulkan bahwa pemanfaatan media audio visual mampu meningkatkan keterampilan menulis puisi pada siswa SMP.

Dalam penelitian ini, dapat dikatakan bahwa penggunaan media audio visual dapat mempengaruhi kemampuan menulis puisi bahasa indonesia. Dengan menggunakan media pembelajaran audio visual secara optimal maka kemampuan menulis puisi siswa juga akan semakin lebih baik. Hal ini dikarenakan media audio visual lebih mudah didapatkan secara gratis dan membuat proses pembelajaran menjadi lebih efisien, selain itu pembelajaran menggunakan media audio visual sangat cocok digunakan dalam pembelajaran jarak jauh, seperti misalnya kemudahan untuk menyampaikan materi, pemberian tugas serta memberikan arahan kepada siswa.

\section{Pengaruh Minat Belajar Siswa terhadap Kemampuan Menulis Puisi}

Untuk dapat menguji hipotesis ketiga, maka data diolah menggunakan program IBM SPSS Statistics 25.0, dengan hasil data sebagai berikut :

\section{Tabel 4. Hasil Uji Hipotesis Kedua}

\section{Coefficients $^{\mathrm{a}}$}

\begin{tabular}{|c|c|c|c|c|c|c|}
\hline \multirow{2}{*}{\multicolumn{2}{|c|}{ Model }} & \multicolumn{2}{|c|}{$\begin{array}{l}\text { Unstandardized } \\
\text { Coefficients }\end{array}$} & \multirow{2}{*}{$\begin{array}{c}\begin{array}{c}\text { Standardized } \\
\text { Coefficients }\end{array} \\
\text { Beta }\end{array}$} & \multirow[t]{2}{*}{$\mathrm{T}$} & \multirow[t]{2}{*}{ Sig. } \\
\hline & & $\mathrm{B}$ & $\begin{array}{l}\text { Std. } \\
\text { Error }\end{array}$ & & & \\
\hline \multirow[t]{2}{*}{1} & (Constant) & 7.575 & 1.928 & & 3.929 & .000 \\
\hline & Minat & .438 & .019 & .593 & 22.672 & .000 \\
\hline
\end{tabular}

a. Dependent Variable: Menulis Puisi

Selanjutnya berdasarkan hasil perhitungan pada tabel 4 minat belajar menunjukan nilai Sig $=0,000<0,05$ dan $t_{\text {hitung }}=22.672>1.987$. Hal ini menunjukan bahwa terdapat pengaruh yang signifikan atas pengaruh minat belajar terhadap kemampuan menulis puisi bahasa indonesia siswa kelas X SMK Negeri di Kabupaten Karawang. Dengan demikian, hipotesis ketiga yang menyatakan 
"terdapat pengaruh minat belajar siswa terhadap kemampuan menulis puisi pada siswa kelas X SMK Negeri di kabupaten Karawang”, terdukung/diterima.

Hal ini sejalan dengan penelitian yang dilakukan oleh Apriani (2017) dalam jurnalnya berjudul "Pengaruh Minat Belajar Terhadap Kemampuan Menulis Karangan Narasi pada Siwa" menyimpulkan bahwa minat belajar memiliki pengaruh terhadap peningkatan kemampuan menulis siswa.

Dalam penelitian ini, menyatakan bahwa minat belajar dapat mempengaruhi kemampuan menulis puisi. Karena untuk dapat membuat karya sastra khususnya menulis puisi, perlu adanya dorongan dari minat untuk dapat menarik perhatian siswa dalam suatu pembelajaran. Sehingga siswa dapat dengan mudah memahami materi pembelajaran dan juga siswa terdorong untuk dapat membuat secara mandiri dan kreatif.

\section{SIMPULAN}

Berdasarkan hasil analisis data yang telah dilakukan oleh peneliti, maka dapat ditarik beberapa simpulan, yaitu terdapat pengaruh signifikan secara bersama-sama atas penggunaan media pembelajaran dan minat belajar terhadap kemampuan menulis puisi bahasa indonesia siswa kelas X SMK Negeri di Kabupaten Karawang. Hal ini dibuktikan dengan perolehan nilai Sig 0,000 $<0,05$ serta nilai $\mathrm{F}$ hitung sebesar 715,855 > 3,95, terdapat pengaruh yang signifikan atas penggunaan media audio visual terhadap kemampuan menulis puisi pada siswa kelas X SMK Negeri di Kabupaten Karawang. Hal ini dibuktikan dengan perolehan nilai Sig $=0,000<0,05$ dan $t_{\text {hitung }}=25.357>1.987$, dan terdapat pengaruh yang signifikan atas pengaruh minat belajar terhadap kemampuan menulis puisi bahasa indonesia siswa kelas X SMK Negeri di Kabupaten Karawang. Hal ini dibuktikan dengan perolehan nilai Sig $=0,000<0,05$ dan thitung $=22.672>1.987$.

Berdasarkan hasil penelitian dan simpulan, saran yang dapat peneliti ajukan bahwa peneliti selanjutnya diharapkan mampu menemukan faktor lain untuk diteliti yang berpengaruh terhadap kemampuan menulis siswa, karena penelitian ini baru mengungkap sebagian kecil permasalahan yang berhubungan dengan kemampuan menulis, peneliti selanjutnya diharapkan mampu menambahkan metode-metode penelitian lain agar mendapatkan hasil yang lebih akurat, dan guru diharapkan dapat mengoptimalkan penggunaan media pembelajaran berbasis teknologi dan meningkatkan metode pengajaran yang lebih baik.

\section{DAFTAR PUSTAKA}

Apriani, H. (2017). Pengaruh minat belajar terhadap kemampuan menulis karangan narasi pada siwa. Di akses dari http://dx.doi.org/10.30998/deiksis.v9i03.1802

Dalyono, M. (2009). Psikologi pendidikan. Jakarta. Rineka Cipta

Emeralda R.T., Suryanto, E., \& Rakhmawati. (2019). Peningkatan motivasi belajar dan kemampuan menulis puisi dengan media audio visual pada siswa SMK. Surakarta: Universitas Sebelas Maret. 
Munadi, Y. (2010) Media pembelajaran .Gaung persada. Jakarta: (GP) Press.

Supriantini. (2017). Penerapan media audio visual dalam meningkatakan keterampilan menulis puisi siswa kelas VIII SMP Negeri 13 Palembang. Palembang: FKIPUMP

Suryaman, M. (2010). Strategi pembelajaran sastra (diktat mata kuliah). Yogyakarta: JPBSI FBS UNY.

Tarigan, H. G. (2008) Menulis sebagai suatu keterampilan berbahasa. Bandung. Angkasa

Tarigan, H. G. (2013). Menulis sebagai suatu keterampilan berbahasa. Bandung. Angkasa 